IBIMA Publishing

The Journal of Organizational Management Studies

https://ibimapublishing.com/articles/JOMS/2021/847128/

Vol. 2021 (2021), Article ID 847128, 11 pages, ISSN: 2166-0816

DOI: $10.5171 / 2021.847128$

Research Article

\title{
The Crisis Management and the Civil Protection in Poland
}

Grzegorz PIETREK

\author{
WSB Banking University in Gdansk, Poland \\ gpietrek@wsb.gda.pl
}

Received date:7 September 2020; Accepted date: 22 January 2021; Published date: 5 May 2021

Academic Editor: Agnieszka Szczudlińska-Kanoś

Copyright (C) 2021. Grzegorz PIETREK. Distributed under Creative Commons Attribution 4.0 International CC-BY 4.0

\begin{abstract}
The system of the civil protection in Poland has numerous challenges ahead of it and changes which are unavoidable. It seems to be essential for the execution of tasks associated with the civil protection to be consistent with tasks performed in frames of the crisis management. In this way, the system of the crisis management, harmonized and supplemented, takes action in favor of the civil protection. In contingencies they are endangered different values. Mainly for exchange oneself life and human health, possessions in great sizes or also natural environment. The research purpose of this article is to present the essence of crisis management in Poland and the related civil protection issues. On this basis, differences and similarities in both conceptual and functional layers will be indicated. This will form the basis for conclusions and proposals on the functioning of these security areas in Poland. In order to achieve the intended research objective, the author of this article first carried out a critical analysis of the literature of the subject, mainly Polish, since this area is the concern of the text. The two systems (crisis management and civil protection) were analyzed and compared. Through the use of other research methods, including induction, deduction and synthesis and abstraction, a number of generalizations have been made, allowing for the formulation of final conclusions which synthetically indicate further prospects for system development, integration and evolution.
\end{abstract}

Keywords: Crisis Management, Civil Protection, Government.

Cite this Article as: Grzegorz PIETREK (2021)," The Crisis Management and the Civil Protection in Poland", The Journal of Organizational Management Studies, Vol. 2021 (2021), Article ID 847128 , DOI: $10.5171 / 2021.847128$ 


\section{Crisis Management}

In the European Union, the emphasis on crisis management has been laid in a different way. Crisis management is more focused on the political dimension of security than on undertakings which immediately satisfy civilians' needs. Such an approach suggests that the European Union is focused on the limitation of threats, preparation for response and recovery after a particular event to the normal state of affairs. Hence, response has been left to the countries.

"Crisis management" as a term entered the vocabulary for good after the end of the Cold War. This term appeared in place of another, replacing (in Poland) the concept of civil defense, which in its Cold War dimension was exhausted at the end of the twentieth century. For the record, "civil defence" at the end of the Cold War was defined as an undertaking that could significantly reduce the impact of all forms of military action on civilians, including conventional, nuclear, chemical and biological attacks. These projects were generally passive, unrelated to defence activities within the remit of the armed forces.

Considering the implementation of humanitarian tasks, civil defence used to perform an important role in civil protection when a threat of the use of mass destruction weapon was real. At that time, considering its basic assumptions, the structures of civil defence were usually located at the ministries of defence. However, in new conditions related to security, it required some changes, because until then, civil defence tasks had mainly referred to two or three stages:

- Preparation to the global war;

- Response to the outbreak of the global war;

- General reconstruction after total destruction (the use of nuclear weapon).

Hence, preparations were made with regard to the war, with a possibility to use the structures of civil defence during the time of peace. Considering the new conditions, there was a number of notions which required redefinition, a number of better solutions to be found and new concepts to be defined. A new integrated system had to be developed, which was supposed to include all the entities and the whole society.

New solutions mainly considered the recognition and elimination of risk factors, risk modeling, prevention of threats and recovery after disasters that would be adjusted to the relevant requirements. Such an approach emphasized the universal character of the systemic solutions, integration of the systems in terms of their capabilities to face any dangers and their civil (non-military) character.

The first specified concept refers to the suggestion presented by FEMA (the Federal Emergency Management Agency) in the USA. The concept presents a closed cycle of crisis activities consisting of four stages:

- Mitigation;

- Preparedness;

- Response;

- Recovery.

Each of the stages has been assigned to 12 to 15 undertakings which provide them with the required efficiency. Crisis management has already gone through numerous modifications. In 2007 in the USA, under the supervision of FEMA, a group of specialists and scientists developed general principles which, since then, have been adapted in various countries. These are namely:

1. Universality - it refers to all threats, stages and entities that are responsible (threat addressees) and those exposed to risk;

2. Development capabilities undertaken activities optimise readiness. A developed society is resistant to catastrophes and can face difficult situations; 
3. Risk endurance - the use of risk management achievements for the development of priority rankings and for the securing of resources;

4. Integrity - making all the levels of authority, all the elements and links of a society concentrate their efforts on the priority aims;

5. Cooperation - the development and implementation of broad, transparent relations which are based on honesty, including team work performed by individuals, communities, teams and organisations which are based on trust and understanding;

6. Coordination - it consists in the synchronisation of activities performed by all the threat addressees in order to achieve a common aim;

7. Flexibility - it results from creativity and innovativeness in the approach towards solving problems connected with catastrophes;

8. Consequence - it results from the rationality of the activities performed in the field of security - there is no room for negligence and abandonment in the field of crisis management;

9. Harmony - it consists in the development, implementation and permanent verification of standards and crisis law;

10. Professionalism - it refers to the superiority of science and knowledge based on education, training, exercises, practice, ethics, values, efficiency and permanent improvement.

Considering the point of view presented in this article, it should be advisable to notice that during the recent years, the perception of crisis management has changed. It has been perceived in systemic categories. That means a pursuit of integration but not of the centralisation of various elements, links, micro-systems and sub-systems into one integrated system which shall include all the actors in the field of security. It shall refer to all the levels (government, selfgovernment, non-government), sectors (public, private, cooperative, communal) in all the stages and in the reference to all threats, with the use of all the available resources (civil emergency planning).

Having emerged and strengthened among practitioners and theoreticians, a modern concept of crisis management has also been recognised by international organisations. The International Association of Emergency Managers (IAEM) can be taken as an example. It is a non-profit organisation which has been established to promote protection of life and property during disasters. Similar great merits in the development of crisis management standards are assigned to the World Bank, which, in 2006, established the Global Facility for Disaster Reduction and Recovery (GFDRR). It turned out to be of great significance for the long-term partnership in the field of loss reduction during disasters through the channeling, modification and reduction of disaster risk. Such activities of the World Bank forced the rational use of financial means in the field of security, because states and international organisations, who wanted to acquire funds for the implementation of some undertakings, were forced to follow systemic reinforcement of their crisis readiness through the formalisation and legitimisation of the recovery stage.

Also in the European Union, some positive tendencies could be observed. However, it was only in 2001 when the Community Mechanism in the field of civil defence was accepted and implemented (a counterpart of crisis management in the EU terminology). It was a significant fact for the unitary character of such activities, because the main aim was to systematise cooperation in civil defence and support provided to the EU members in that respect. It referred to major disasters, because minor disasters were left in the national competences of the states. The novelty was the fact that there appeared activities which preceded a disaster (prevention and preparedness). 
The Generic Crisis Handbook also cites an interesting definition of crisis management according to NATO's concept. In line with this concept, crisis management should be seen broadly, taking into account the procedures and actions aimed at taking control of the crisis situation by crisis managers, enabling them to shape the course of the crisis through preparatory actions.

Western states also made their attempts at some legislation efforts in the field of the systematisation of crisis law. Most legal acts from that period came from the years 2001-2005, that is namely: after the attack on the WTC on $11^{\text {th }}$ September 2001.

The acquired knowledge, experience and disasters which had been faced, forced the EU states and NATO to make general changes in their security systems. At that time, the structures of civil defence were still under their liquidation, because they had been considered non-adjustable to the conditions of a decentralised society. However, practicism suggested that some of their elements should be used in the redevelopment of the new systems. The new situation required verification of axioms and solutions, performance of research and implementation of research results, training provided to services, new law and adaptation to the surrounding reality.

The crisis management system is aimed at decreasing the risks related to the possibility of threats and also at the development of activities that would provide security to people, protection of critical infrastructure and natural environment. Hence, it is one of the most important systems which affects the functioning of the state and the sense of security in its citizens. Therefore, it can be assumed that the priority objective of the operation of that system is the implementation of the tasks which provide proper civil protection, which should be nowadays understood as a set of activities undertaken by the relevant public authorities, rescue units and humanitarian organisations, as well as by individual citizens, which are to provide security to the whole society.

\section{Civil Protection}

Civil protection is defined in a different broad sense by Waldemar Kitler, who identifies it as one of the fundamental missions implemented for national security by state administration authorities, other state bodies and state institutions, entrepreneurs and other organisational units, non-government organisations and citizens themselves, and in some justified cases, by the armed forces. Such a mission involves the implementation of numerous preventive, preparatory, interventional and recovering tasks in order to protect life and health of people, to protect their property, objects of cultural legacy and natural environment to the extent indispensable for survival. The mission also involves any humanitarian and legal aid provided during catastrophes, natural disasters, armed conflicts and occupation directly after such events.

Expert literature provides another interesting opinion on the discussed problem. Aleksandra Skrabacz defines civil protection as a set of interdisciplinary undertakings implemented by joint efforts made by all entities of the state law who act in order to protect life, health, property and natural environment against any potential danger caused by the forces of nature or by people, to overcome their consequences and to provide conditions indispensable for survival.

So far, civil protection has not been defined in any currently binding legal act. It is, however, possible to fall back on a draft act on civil protection of $31^{\text {st }}$ August 2009, article 2 which states that civil protection comes as integrated operation of state administration authorities and entities which implement tasks of civil protection in order to provide security to citizens, public order, protection of life and health of people who reside in the territory of Poland, protection of property, natural environment and cultural legacy in any cases of potential threats. 
The above-mentioned draft act defines the principles referring to the organisation and functioning of the civil protection system, relevant authorities responsible for civil protection and their tasks, as well as entities responsible for the implementation of these tasks. The draft act also defines the principles of alarming and warning, education of people, citizens' rights and obligations. Additionally, the document states the main assumptions of the practical implementation of civil protection, viewed through the prism of the following:

- Providing

conditions indispensable to protect human life and health, to provide people with basic conditions necessary to survive in emergency situations;

- Providing cooperation of all the rescue systems, monitoring, warning, alarming, informing about potential threats, also units, services and other entities which implement tasks for civil protection;

- Providing substantive, organisational, material and financial support to the operations implemented by non-government organisations which perform tasks for civil protection, particularly to social rescue and humanitarian organisations and voluntary service;

- Organisation and coordination of humanitarian aid;

- Maintaining resources which may be used to implement tasks for civil protection;

- -Providing education to society members to increase the awareness of potential threats and to promote the proper behaviour in case such threats take place.

It seems indispensable to accept and implement a new regulation on civil protection. In fact, there is such a project, however, since 2009 the related legislation work has not been finished yet. While analysing that document, it is possible to find a number of very significant elements there, the implementation of which would be favourable for its assumed aim, that is namely: the development of a relevant legal framework in order to provide conditions indispensable for protection of human life and health, basic conditions for the survival of people in emergency situations, cooperation of rescue systems, authorities, services and other entities which implement tasks in the field of civil protection, improvement in coordination, receiving and providing humanitarian aid, providing proper resources used in rescue operations and civil protection. The contents of the draft act allows us to draw a rightful conclusion that should also strongly emphasize the development of the awareness in the society and the promotion of the proper behaviour in the face of threats in order to increase security and to decrease any direct consequences resulting from such threats. The act should pay particular attention to the processes of prevention and preparedness which are undertaken in order to minimise natural or man-made threats. An important point in the implementation of the act is the development of a mechanism which enables people who work in social, rescue and humanitarian organisations to acquire indispensable knowledge and skills, along with the protection of their legal interests. The protection of interests of employers who employ the above-mentioned people comes as another important aspect which makes the whole mechanism work properly.

Based on the above-mentioned range of tasks and a pragmatic approach towards the question of civil protection, it is advisable to pay some attention to the institutional context of their implementation, namely: the specification of entities which are competent to perform such tasks.

There is another important opinion worth noticing provided by Romuald Kalinowski who sees civil protection as an institution (in this case: a formation) that is: Civil Protection. For Kalinowski, civil protection - considered in a systemic approach as well as in an individual one - is significant because of the legal and humanitarian approach of various entities towards that 
issue. He indicates that it is important to provide civil protection to the whole population of the country in the time of peace as well as in the time of war.

Considering the semantic approach, the above-mentioned W. Kitler states that the term civil defence may refer to: civilians' resistance or civil fighting, non-military protection, civil (non-military) protection, facing threats by civilians, aid and self-aid in the society, social self-defense, and civil power used in defensive fights. It can also describe non-military power and means applied for fight, defence, protection and self-defense; it can refer to the method of fighting with the use of non-military tools, the character, the type and the set of defensive or protective operations performed with the use of non-military tools and activities undertaken by civilians in the face of military and non-military threats.

Putting aside the changes which have taken place in the way of understanding the term civil defence, it is possible to assume that it comes as one of the most important components in the national defence system which functions within the framework of the so called non-military defence system. In the world, civil defence operates on the basis provided by the regulations of the Geneva Convention of $12^{\text {th }}$ August 1949 , with Amendment Protocols ratified by Poland in 1991. In Poland, legal regulations referring to civil defence can be found, first of all, in the Act on General Obligation to Defend the Republic of Poland, of 1967. According to the author, one of the most important concepts which results from the analysis of that document is the indication that organisations (structures) of civil defence in the time of peace may be applied for cooperation in fighting against natural disasters, threats to natural environment, in removing their results, organised and led by other authorities.

Therefore, it is possible to assume that civil defence is aimed at the protection of people, places of employment, public facilities, objects of cultural legacy, rescue operations and support provided to victims in the time of war and at cooperation in fighting against natural disasters, threats to natural environment and removing their results. It is also possible to clearly conclude that the time range of the functioning of civil defence has not been confined only to the time of war (as it is commonly thought).

Considering the aspect of time of peace and time of war, some theoreticians state that the division between civil protection during the time of peace and civil defence during the time of war is irrelevant. They claim that regardless of the time, the right notion is civil defence, which in turn should be divided into civil protection, general rescue services, and other tasks. Considering the systemic approach, the above-mentioned author, R. Kalinowski sees a great role performed by Civil Defence as one of the leading entities of the national defence system of Poland, namely: an organisation based on the structures of state administration which implements humanitarian tasks in order to protect people. Hence, civil defence can be perceived in a very broad sense, and it can be defined as a system of civil protection in Poland which consists of an operational sub-system of Civil Defence, a sub-system of local support, a sub-system of national support and a sub-system of international support.

Following the thought of the cited author, it is possible to assume that in general, understanding civil defence refers to structures, tasks, operational principles and forces which provide services to people. Considering the modern character of civil defence, it should be emphasized that it is based on the coordinated operation of forces and resources of all the departments, regional authorities of state administration and self-governments, other units, entities and organisations along with a widespread involvement of the whole society. The implementation of tasks takes place in accordance with the principle of territorial primacy, with the consideration of the three-level division of the country, in consistency with the current legal regulations. This is the most proper procedure, considering the aspects of economy, efficiency of operations and 
responsibility for decisions made in the field of civil protection.

The above-presented considerations may lead to a well-grounded conclusion that in Poland's national system, the tasks referring to civil protection against various threats are entrusted to numerous centres, administration structures and selfgovernments. The efficiency of operation is ensured by the collective cooperation coordinating rescue actions undertaken by particular entities.

Considering a number of tasks implemented in that field, A. Skrabacz presents their systematisation, divided into three main modes:

a. Permanent standing-by and ad hoc response - performance of routine activities oriented towards rescue of people, property and natural environment; elimination of direct results of sudden emergency situations; prevention and counteraction undertaken against any potential threats;

b. Crisis - response to situations in which any direct threat may lead to a crisis, and response during an ongoing crisis;

c. Armed conflict (war) - civil protection in accordance with the regulations of international law.

Considering the high level of the implementation of undertakings which are aimed at civil protection, the same author also suggests the following principles which should systemise such implementation:

- Primacy of a territorial system; it means that the foundation of the whole model of civil protection is a horizontal system of authorities formed on the basis of a three-level division of the country, in which the department system performs only an auxiliary function;

- One-person leadership and responsibility for the standing-by mode to provide civil protection; it does not mean any resignation from teams who provide opinion and advice, but it implies resignation from making decisions by a collective body;

- The adequacy of the character and scale of a threat and of the level of the state administration authority which should respond to such a threat; it means that all activities should be performed by the lowest level of competences in a particular situation;

- The common character of the civil protection system means that it refers to all the citizens, and it imposes particular tasks and obligations on them, depending on a situation in which the stand-by system is functioning at a particular moment;

- Management and responsibility held by one-person authorities of general administration: a village head, a starost as the self-government authorities of a borough and a district, and a provincial governor (voivode) who represents government authorities at the level of the province.

Hence, the area in which the tasks of civil protection are implemented is very broad. It is advisable to provide a systematisation of the problem, as I. T. Dziubek suggests. The discussed undertakings are divided by the category of the tasks implemented for:

- Collective protection - it comes as a systemic activity run by relevant institutions; it involves the recognition of threats and alarming, providing proper shelter, evacuation and blackout;

- Individual protection - various activities undertaken by citizens who are prepared to behave adequately to particular situations.

In reference to the above-presented considerations, it is possible to conclude that further development of civil protection structures is inseparably connected with the development of the crisis management system. In accordance with the legal act, the latter system has been developed in 
order to carry out preventive and rescue operations and to reconstruct the critical infrastructure in case of any potential threat. The system of civil protection in Poland faces numerous challenges, and it has to undergo some inevitable changes. It seems necessary to make the implementation of civil protection tasks cohesive with tasks implemented within the framework of the Act on Crisis Management in such a way that the crisis management system should cooperate and complete activities performed for civil protection. Considering civil defence, it is possible to observe that solutions and structures applied for the tasks are dispersed in various legal regulations, and sometimes they are not covered by any of them. Therefore, it is possible to suggest some regulations in that field, for example:

- Definition and introduction of a term of civil protection into legal regulations - so far it has not been done, hence, there is some terminological chaos in that respect;

- Explicit indication and identification of tasks assigned to state administration authorities in the field of civil protection, and consequently, indication of authorities responsible for the implementation of such tasks at the level of a borough, a district, a province and the country;

- A new definition of the way in which the state should implement civil defence tasks referring to the protection of victims of international armed conflicts - it should be considered whether particular entities who perform civil protection tasks should be granted a status of entities performing civil defense tasks in the time of armed conflict (war) in an automatic, statutory way.

It also seems necessary to provide statutory regulations referring to tasks performed to rescue life, health, property and natural environment, to provide aid to those who need ad hoc humanitarian support in the time of peace and in the time of emergency. It can be specified in a single legal act which would indicate such elements as: principles of providing humanitarian aid, citizens' obligations in the field of civil protection, programmes of civil protection, methods and principles of informing, warning and alarming, tasks and entities responsible for education and training provided to citizens, shelters provided to people, protection of property in emergency situations, methods and principles of creating resource reserves, definition of the functioning of civil protection during the "W" period; the funding of tasks, and penal regulations.

Such a solution does not come down to the development of new structures. It should be considered whether the structures responsible for that issue are the structures of the crisis management system or the structures of the civil defence system, all the more that some of the abovementioned tasks are implemented based on some other legal acts. In order to introduce new solutions, it is first necessary to identify entities of civil protection, because it is possible to assume that they shall be activated during the state of emergency, and in the state of mobilisation, they could be transformed in National Defence in the time of an armed conflict or war.

It seems advisable to place tasks of civil protection and civil defence in the current system of national security as well as in the latest solutions which refer to crisis management and general defence obligation (e.g.: the conscription of Territorial Defence Forces), in order to properly and clearly define the competences of territorial self-government authorities. Consequently, it would be possible to implement civil protection tasks, adjust legal regulations to current threats, and improve ways of response to such threats.

There is one more conclusion: the perception of the implementation of civil protection tasks takes place through the prism of civil defence. It is not surprising though, considering the stages of civil defence development 


\section{Integration of the systems}

The crisis management system and the civil defence system have a lot in common. Planning can be considered $s$ an example. At each of their operational levels, bodies and institutions involved into civil defence must follow their plans, as they take place at each level of crisis management. The detailed content of civil defence plans and the content of crisis management plans are similar. However, despite the fact that there are some consistencies, it should be emphasized that the civil defence plan is to be applied during a situation of external threats to the national security and during the time of war, whereas the crisis management plan is to be applied during the time of peace. It can be an indication referring to the necessity and tendency to maintain the structures of civil defence in Poland. Although at present, civil protection is perceived through the prism of crisis management, and as a result, civil defence is pushed into operation exclusively during the time of war, it does not mean it cannot be used during a crisis.

A decision made by the government on the Programme of Rescue Services and Civil Protection in 2014-2020 seems to be very promising. It is actually the first document which - in a holistic and complete way describes the problems referring to the organisation of rescue operations undertaken to protect life, health, property and natural environment by all public and social entities which perform such tasks. The resolution No. 59/2014 of the Council of Ministers of 29th April 2014 on the acceptance of the Programme of Rescue Services and Civil Protection in 2014-2020. The programme is to define objectives which must be achieved in the field of rescue services and civil protection in the years 2014-2020, conditions which must be met to achieve such objectives, with all the basic but indispensable legal, financial and organisational instruments. The suggested solutions shall be applied to provide a comprehensive support and development of the potential of national security within which, an executive subsystem is operated, namely: protective capabilities formed by services and organisations which implement rescue and civil protection tasks, along with entities of the crisis management system.

An important element which improves the crisis management system is the incorporation of the problems of civil protection into the field of crisis management, and the integration of the current systems through new legal regulations, including integration of tasks and structures. New legal regulations should provide a framework for conditions indispensable for the protection of human life and health, basic conditions for survival, cooperation of systems, authorities, services and other entities which perform civil protection tasks; for improvement in the coordination of humanitarian aid and, additionally, for securing proper resources.

Another element is the incorporation of a range of tasks referring to the field of civil protection, which come as a particular form of civil protection implemented by the same authorities and executive entities during the time of war. It is related to the international obligations of Poland and the possibility to integrate pre-prepared organisational and legal solutions which function during the time of peace, with the rescue elements, and during the time of war. Considering the anachronistic character of the solutions applied in the currently functioning civil defence, it is necessary to implement new legal regulations which enable the state authorities to meet their obligations in the field of the broadly understood security provided to citizens in the time of war and peace.

\section{Summary}

The civil protection system in Poland is multi-element. It can be concluded that specialists in this field have a considerable problem with determining the components of this system. According to the authors, it can be pointed out that the civil protection system operates a crisis management subsystem (together with some of the implementing elements - and here the State Fire Service - which is important for the rest of the process). In addition, it can 
be included in the system of rescue subsystem (among others, the National Rescue and Fire-Fighting System - headed by the Commander-in-Chief of the State Fire Brigade), including the Armed Forces of the Republic of Poland or the State Medical Rescue. In addition, it is complemented by an element related to Civil Defence, which is now more of a theoretical subsystem than a practical one. Civil defence is based on the General Obligation to Defend the Republic of Poland Act 1967, and is generally adapted to the conditions of military conflict or crisis with such elements. Very often, the rescue, civil defence and crisis management systems are confused with and conceptually mixed.

Considering the functioning of the civil protection systems and their integration, it seems necessary to provide statutory regulations referring to tasks performed in the field of rescuing human life and health, property and natural environment, providing ad hoc humanitarian aid to the people in need in the time of peace and in emergency situations. It would be possible to develop, through a specification confined in one, a relevant legal act that would integrate all the dispersed elements. However, it would not be advisable to develop new structures, and the tasks should be entirely entrusted to the units of the crisis management system or civil defence, even though that some tasks have been already implemented on the basis of some other legal acts. In order to implement new solutions, a prior identification of civil protection entities shall be necessary, because it can be assumed that they shall be activated during natural disasters, and in a situation when mobilisation is announced, such entities could be transformed into Civil Defence during the time of war or a military conflict.

The civil protection and crisis management system in Poland must be universal and interdisciplinary. It should reach the lowest levels of local government and a large number of companies, workplaces, museums and cultural institutions. The new generation of threats, including not only hybrid threats and those below the threshold of war, but also those we are currently facing, must be faced by the state with instruments that support and complement the work of specialised services, but above all, relieve them when necessary.

The civil protection system in Poland faces numerous challenges and changes which are unavoidable. It seems necessary to make the implementation of civil protection tasks consistent with tasks implemented within the framework of the act of crisis management, in such a way that the crisis management system should cooperate and complete operations undertaken for civil protection.

\section{References}

- Dziubek, I T. (2013) Edukacja obronna w Polsce, ZYSK i s - ka,Poznań.

- Gołębiewski, J. (2015) Zarządzanie kryzysowe na szczeblu samorządowym. Teoria i praktyka, Difin, Warszawa.

- $\quad$ Kalinowski, R. (2011) Obrona cywilna w Polsce, UPH, Siedlce.

- Kitler, W. (2001) Obrona cywilna (niemilitarna) w obronie narodowej III RP, AON, Warszawa.

- Kitler, W., Skrabacz, A. (2010) Bezpieczeństwo ludności cywilnej. Pojęcie, organizacja i zadania w czasie pokoju, kryzysu i wojny, TWO, Warszawa.

- Skrabacz, A. (2008) Obrona narodowa w tworzeniu bezpieczeństwa Polski w XXI wieku, Warszawa.

- Sobolewski G. (2013) Metodologia badań bezpieczeństwa, AON Warszawa.

- Appendix to the Resolution no. 17 of the Council of Ministers of 12th February 2013 (item 136) on adopting the Efficient State 2020 strategy.

- Generic Crisis Handbook, (1997) NATO Office of Information and Press, Brussels.

- Compendium of Guidelines for the Basic Protection of Population (1986), NATO, document AC/23-D/791/86.

- The draft act on civil protection of 31 st August 2009, article 2. 